\title{
1 Role of air temperature and humidity in the transmission of SARS-CoV-2 in the United
}

\section{States}

3 Yiqun $\mathrm{Ma}^{1,2}$, Sen $\mathrm{Pei}^{3^{*}}$, Jeffrey Shaman ${ }^{3}$, Robert Dubrow ${ }^{1,2}$, Kai Chen ${ }^{1,2^{*}}$

41 Department of Environmental Health Sciences, Yale School of Public Health, 60 College Street, New

5 Haven, CT, 06520-8034, USA

62 Yale Center on Climate Change and Health, Yale School of Public Health, 60 College Street, New

7 Haven, CT, 06520-8034, USA

83 Department of Environmental Health Sciences, Mailman School of Public Health, Columbia University,

$9 \quad$ New York, NY 10032, USA.

$11 *$ Corresponding authors: K. Chen, Yale School of Public Health, 60 College Street, New Haven, CT,

12 06511, USA, kai.chen@yale.edu; S. Pei, Mailman School of Public Health, Columbia University, New

13 York, NY 10032, USA, sp3449@cumc.columbia.edu

14 
medRxiv preprint doi: https://doi.org/10.1101/2020.11.13.20231472; this version posted November 16, 2020. The copyright holder for this preprint (which was not certified by peer review) is the author/funder, who has granted medRxiv a license to display the preprint in perpetuity.

It is made available under a CC-BY-NC-ND 4.0 International license.

\section{Abstract}

16 Improved understanding of the effects of meteorological conditions on the transmission of SARS-CoV-2,

17 the causative agent for COVID-19 disease, is urgently needed to inform mitigation efforts. Here, we

18 estimated the relationship between air temperature or specific humidity (SH) and SARS-CoV-2

19 transmission in 913 U.S. counties with abundant reported infections from March 15 to August 31, 2020.

20 Specifically, we quantified the associations of daily mean temperature and SH with daily estimates of the

21 SARS-CoV-2 reproduction number $(R t)$ and calculated the fraction of $R t$ attributable to these

22 meteorological conditions. Both lower temperature and lower SH were significantly associated with

23 increased Rt. The fraction of Rt attributable to temperature was 5.10\% (95\% eCI: $5.00-5.18 \%)$, and the

24 fraction of $R t$ attributable to SH was $14.47 \%$ (95\% eCI: 14.37 - 14.54\%). These fractions generally were

25 higher in northern counties than in southern counties. Our findings indicate that cold and dry weather are

26 moderately associated with increased SARS-CoV-2 transmissibility, with humidity playing a larger role

27 than temperature. 


\section{Introduction}

30 Since emerging in Wuhan, China, the novel severe acute respiratory syndrome coronavirus 2 (SARS-

31 CoV-2), the causative agent of coronavirus disease 2019 (COVID-19), has produced a major global

32 pandemic. As of November 12, 2020, approximately 10.6 million COVID-19 cases and 243 thousand

33 deaths had been reported in the U.S. ${ }^{1}$, more than any other country. The decreased stability of SARS-

34 CoV-2 in warmer temperatures and higher humidity in laboratory experiments ${ }^{2,3}$, and the documented

35 seasonality of influenza ${ }^{4}$ and infections caused by other coronaviruses ${ }^{5-7}$, lead to the hypothesis that lower

36 air temperature and lower humidity are associated with increased SARS-CoV-2 transmission. Quantifying

37 this effect on a population level is urgently needed to help inform public health control efforts, including

38 transmission prevention and communication with the public ${ }^{8}$.

39 Numerous preliminary studies have found either positive or negative associations of air temperature and

40 humidity with COVID-19 cases $^{9-13}$. However, given the large number of undocumented SARS-CoV-2

41 infections ${ }^{14}$, the variations in the lag between infection and symptom onset, and the inconsistent lag

42 between testing and reporting, using daily new confirmed cases may not be optimal for examining

43 meteorological effects ${ }^{15}$. As a result, a few studies have used the reproduction number to estimate SARS-

44 CoV-2 transmissibility ${ }^{16-18}$. One study reported high daily air temperature and high daily relative humidity

$45(\mathrm{RH})$ to be associated with a reduced daily effective reproduction number (the mean number of new

46 infections caused by a single infected person in a population in which some individuals may no longer be

47 susceptible due to acquired immunity ${ }^{19}$ ) for SARS-CoV-2 in both China and the U.S. ${ }^{16}$. However, two

48 early studies focused on the first few of months of the pandemic found no association between

49 temperature or humidity and the basic reproduction number (the mean number of new infections caused

50 by a single infected person in a population in which everyone is assumed to be susceptible and no public

51 health measures have been implemented $)^{17,18}$.

52 Early analyses, in particular, should be interpreted with caution ${ }^{8}$, as the range of temperature and

53 humidity measurements during the short observation period at the beginning of the pandemic was 
54 relatively narrow in most studies ${ }^{9-12,16-18}$, thus limiting the ability to detect associations between these meteorological variables and SARS-CoV-2 transmission. In addition, many previous studies (whether using COVID-19 cases or reproduction number as the outcome) controlled for no or only a few potential confounders $^{9-13,17,18}$, which include other environmental factors, socioeconomic factors, temporal changes in population immunity, and implementation of public health interventions. COVID-19 incidence, the fraction of cases or deaths attributable to meteorological conditions remains unclear. One modeling study predicted that as long as most of the population is susceptible to infection, any role of humidity in SARS-CoV-2 transmission would be overwhelmed by the lack of population

63 immunity ${ }^{20}$. This prediction is supported by the rapid transmission of SARS-CoV-2 regardless of climate zone, including warmer locations such as tropical Brazil, India and southern states in the U.S. during the northern hemisphere summer ${ }^{1}$.

Here we investigate the association between air temperature or specific humidity ( $\mathrm{SH}$; the mass of water vapor in a unit mass of moist air $[\mathrm{g} / \mathrm{kg}]$ ) and SARS-CoV-2 transmission, as measured by the reproduction number $R t$ (the mean number of new infections caused by a single infected person, given the public health

69 measures in place, in a population in which everyone is assumed to be susceptible). We estimate $R t$ in the 913 counties with at least 400 cumulative cases as of August 31, 2020 and calculate the fraction of $R t$

71 attributable to temperature or $\mathrm{SH}$, adjusting for a wide range of potential confounders.

\section{Results}

\section{Distribution of meteorological factors and $R t$}

74 From March 15 to August 31, 2020, a total of 4,903,520 cases of COVID-19 were reported in the 913

75 study counties (Extended Data Table 1). We estimated the county-specific $R t$ using a dynamic

76 metapopulation model informed by human mobility data that represents the transmission of SARS-CoV-2

77 in the U.S. (see Methods). Mean daily Rt averaged over all counties and days during the study period was

$78 \quad 1.40$ and ranged from 0.46 to 5.43. Daily air temperature and SH also ranged widely (air temperature: -

$7914.61-39.98{ }^{\circ} \mathrm{C}$; SH: $0.99-22.15 \mathrm{~g} / \mathrm{kg}$ ). Union County, New Jersey had the highest Rt averaged over the 
medRxiv preprint doi: https://doi.org/10.1101/2020.11.13.20231472; this version posted November 16, 2020. The copyright holder for this preprint (which was not certified by peer review) is the author/funder, who has granted medRxiv a license to display the preprint in perpetuity.

It is made available under a CC-BY-NC-ND 4.0 International license .

80

81

82

83

study period (Fig. 1a). The largest number of cumulative cases per 100,000 people was observed in Chattahoochee County, Georgia, while Taylor County, Florida had the lowest number (Fig. 1b). Southern counties generally were hotter and more humid than northern counties; whereas the western U.S., coastal counties generally were cooler and more humid than inland counties (Fig. 1c-d).

\section{a. Average reproduction number}

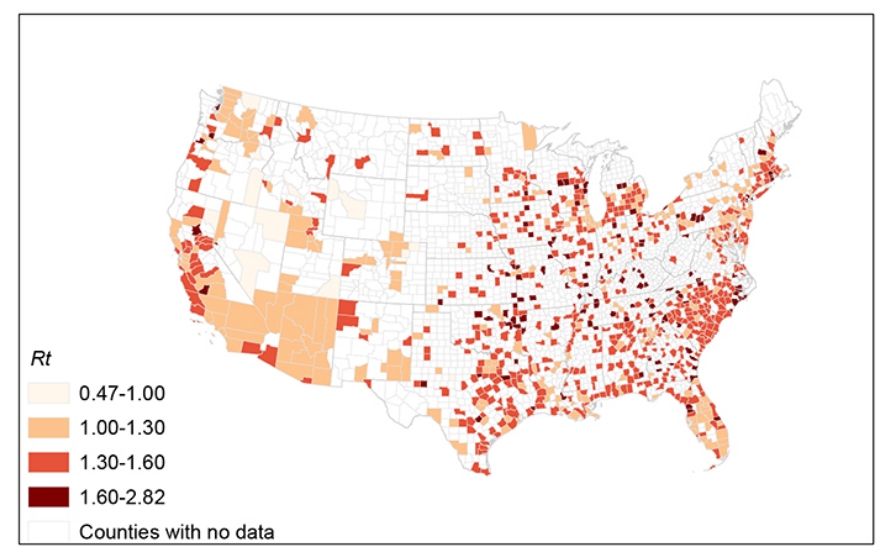

\section{c. Average air temperature}

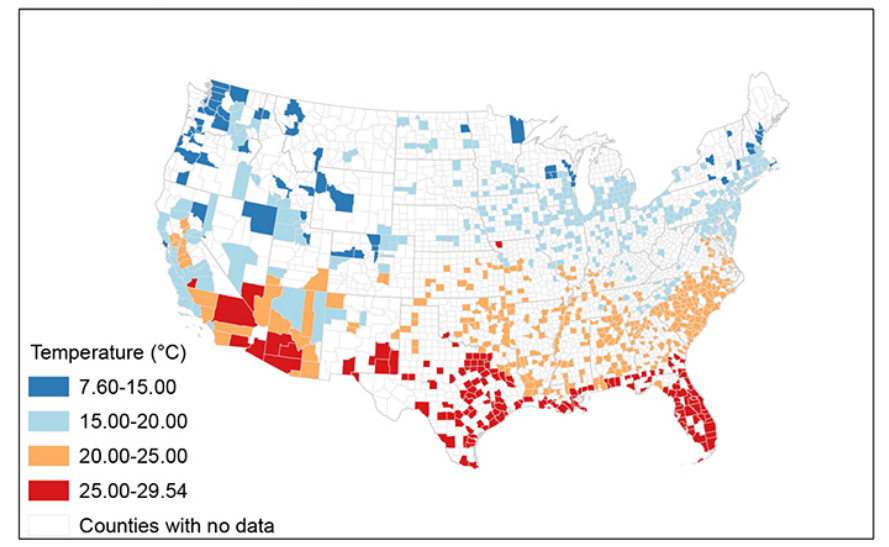

\section{b. Cumulative cases per 100,000 population}

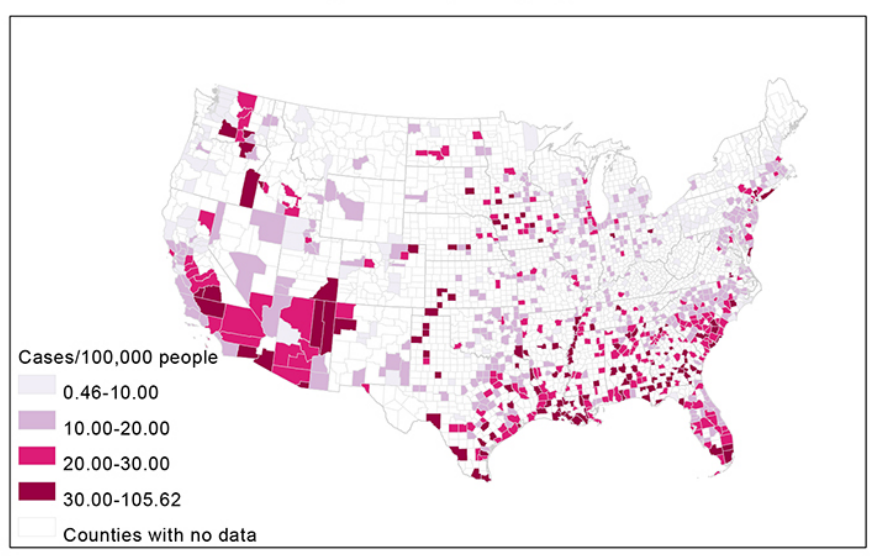

d. Average specific humidity

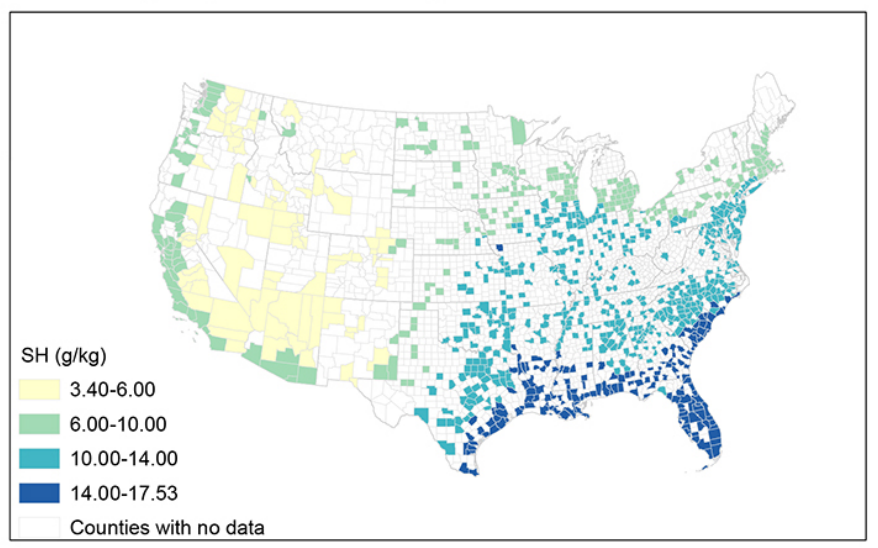

84

\section{Fig. 1. Map of the distribution of reproduction number, cumulative cases, air temperature} and specific humidity in study counties.

These maps display the distribution of the daily reproduction number $(R t)$, daily air temperature, and daily specific humidity (SH) averaged over the study period, and the cumulative cases per 100,000 population, in 913 U.S. counties. 
medRxiv preprint doi: https://doi.org/10.1101/2020.11.13.20231472; this version posted November 16, 2020. The copyright holder for this preprint (which was not certified by peer review) is the author/funder, who has granted medRxiv a license to display the preprint in perpetuity.

It is made available under a CC-BY-NC-ND 4.0 International license .

\section{Associations between meteorological factors and Rt}

92 We estimated the complex non-linear and temporally delayed associations of meteorological factors with

93 the SARS-CoV-2 Rt using a generalized additive mixed model adjusting for spatiotemporal variations in

$94 R t$ and potential measured confounders, described in detail in Methods. We then calculated the optimum

95 values of temperature and $\mathrm{SH}$, which correspond to the lowest $R t$. We found an approximately linear

96 inverse temperature-Rt relationship (Fig. 2a), with lower air temperatures significantly associated with

97 increased transmission of SARS-CoV-2 when below the optimum temperature $\left(32.57^{\circ} \mathrm{C}\right)$. No significant

98 associations were observed for temperatures above the optimum value. The relationship between $\mathrm{SH}$ and

$99 R t$ was non-linear (Fig. 2b). Higher SH was significantly associated with decreased transmission, except

100 for an increasing trend from approximately 9 to $15 \mathrm{~g} / \mathrm{kg}$. The optimum SH was estimated to be 19.78

$101 \mathrm{~g} / \mathrm{kg}$. Compared with the optimum value, the $10^{\text {th }}$ percentile of the distribution of air temperature $\left(8.8^{\circ} \mathrm{C}\right)$

102 or SH (4.5 g/kg) was associated with a $14.10 \%$ (95\% CI: $8.59-19.89 \%)$ and $27.49 \%$ (95\% CI: 21.93 -

$10333.30 \%$ ) increase of $R t$, respectively. Effect estimates showed a decreasing trend in the lag dimension,

104 diminishing to a small non-significant effect on lag day 13 (Extended Data Fig. 1). Sensitivity analyses

105 showed the estimated relationships between air temperature or SH and $R t$ were generally consistent under

106 different modeling choices (Fig. 2a-b). 
a. Air temperature

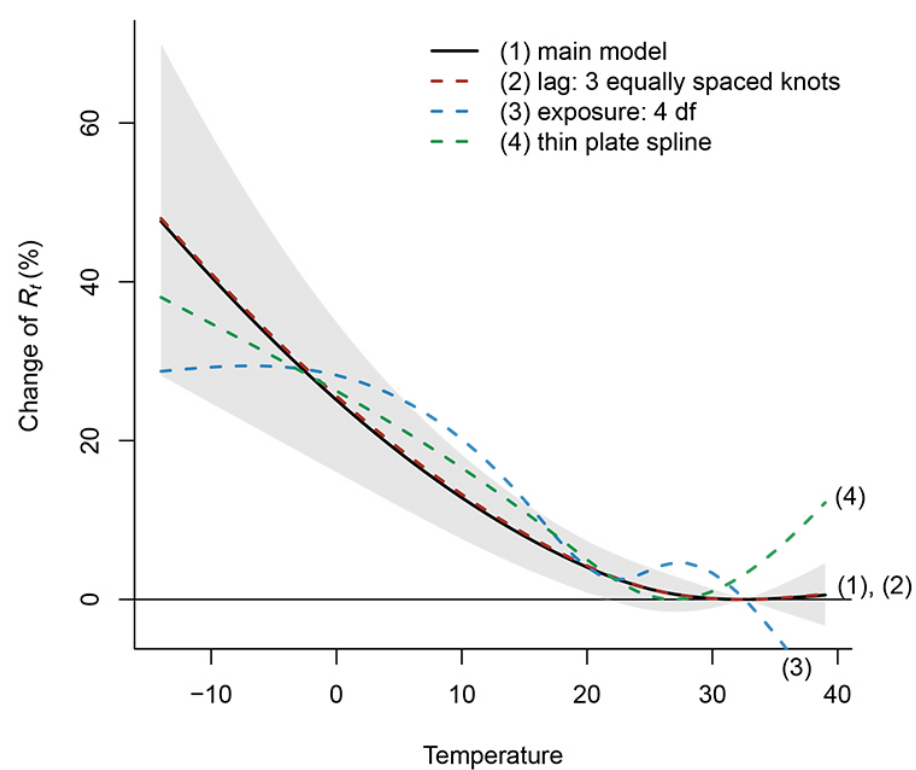

b. Specific humidity

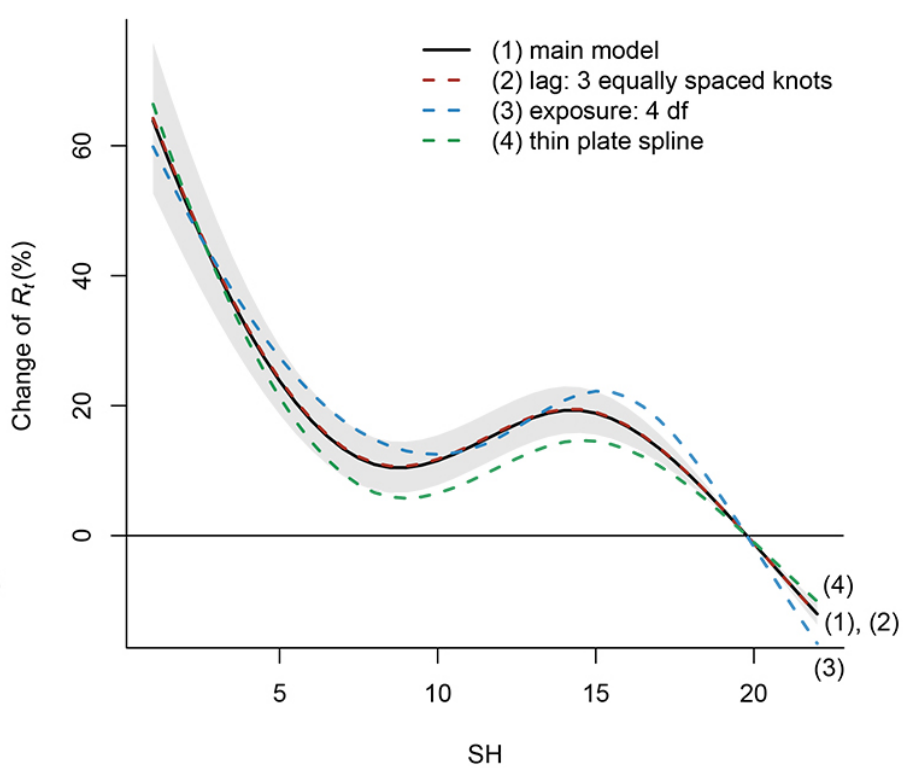

107

108

109

Fig. 2. The associations of air temperature $\left({ }^{\circ} \mathrm{C}\right)$ and specific humidity $(\mathrm{g} / \mathrm{kg})$ with $R t$, under different choices of model.

This figure shows the estimated exposure-response curves for the associations of air temperature $\left({ }^{\circ} \mathrm{C}\right)$ and specific humidity $(\mathrm{g} / \mathrm{kg})$ with reproduction number $(R t)$ for SARS-Cov-2, with different modelling choices: (1) main model with 95\% confidence interval (grey area): tensor product smooths to control for the temporal and spatial variations, and a cross-basis term for air temperature and $\mathrm{SH}$, which is defined by natural cubic splines with $3 \mathrm{df}$ for both the exposure-response and lag-response association, with a maximum lag of 13 days; (2) redefine the lag dimension using a natural cubic spline and 3 equally placed internal knots in the log scale; (3) change the df to 4 in the cross-basis term for air temperature or SH in the exposure-response function; (4): use a thin plate spline to control for geographical coordinates and time instead of using the tensor product smooths.

\section{Fractions of Rt attributable to meteorological factors}

Based on the estimated exposure-response curves and daily county-specific $R t$, we further calculated the fraction of $R t$ attributable to temperature or SH (i.e., the attributable fraction (AF), which can be interpreted as the fraction of $R t$ attributable to the deviation of temperature or SH from the optimum value). Across all 913 counties over the entire study period, the AF for temperature was $5.10 \%$ (95\% 
medRxiv preprint doi: https://doi.org/10.1101/2020.11.13.20231472; this version posted November 16, 2020. The copyright holder for this preprint (which was not certified by peer review) is the author/funder, who has granted medRxiv a license to display the preprint in perpetuity.

It is made available under a CC-BY-NC-ND 4.0 International license .

125 empirical confidence intervals [95\% eCI]: 5.00 - 5.18\%), and the $\mathrm{AF}$ for $\mathrm{SH}$ was $14.47 \%$ (95\% eCI: 14.37

$126-14.54 \%$ ) (Extended Data Table 2). The AF for temperature showed an increasing trend from south to

127 north (Fig. 3a). The county with the highest AF for temperature was Whatcom County, Washington

128 (12.88\%) and the county with the lowest AF for temperature was Hidalgo County, Texas (0.52\%). The

129 AF for SH showed an increasing trend from south to north in the eastern U.S., whereas in the western

130 U.S., the AF for SH was lower in counties in coastal states than in counties in interior states (Fig. 3b). The

131 county with the highest AF for SH was Nye County, Nevada (27.47\%), and the county with the lowest

132 AF for SH was Plaquemines Parish, Louisiana (7.24\%). The AF for temperature was the largest in March

133 and April, and the lowest in July and August (Fig. 3c). The AF for SH showed a modest decline between

134 March and August (Fig. 3d).

135 Sensitivity analyses indicate that the AF for air temperature remains robust when excluding

136 socioeconomic factors and when additionally adjusting for smoking and obesity prevalence, long-term air

137 pollution, or short-term air pollution (Extended Data Table 2). However, the estimated AF for

138 temperature decreased from $5.11 \%$ to $3.55 \%$ after additionally adjusting for daily ultraviolet (UV). The

139 AF for $\mathrm{SH}$ was robust across all sensitivity analyses. 
medRxiv preprint doi: https://doi.org/10.1101/2020.11.13.20231472; this version posted November 16, 2020. The copyright holder for this preprint (which was not certified by peer review) is the author/funder, who has granted medRxiv a license to display the preprint in perpetuity.

It is made available under a CC-BY-NC-ND 4.0 International license .

a. AF to air temperature by county

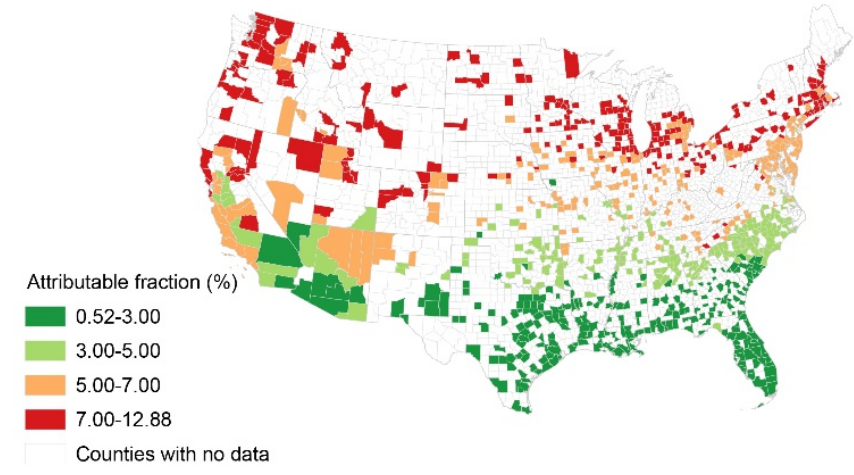

b. AF to specific humidity by county

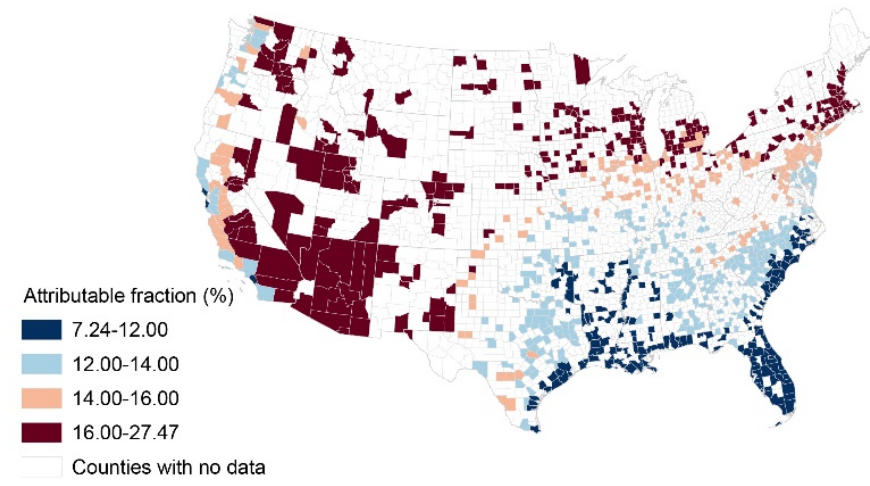

c. AF to air temperature by month

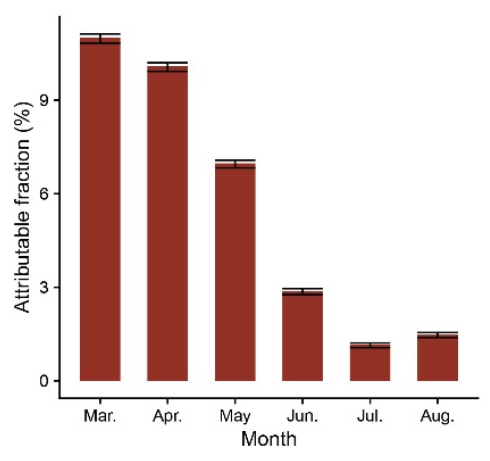

d. AF to specific humidity by month

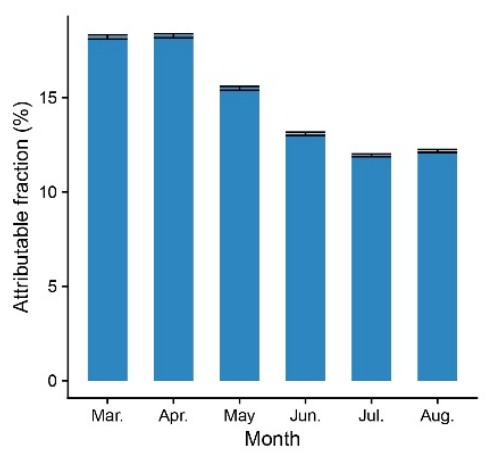

141 Fig. 3. Fractions of $\boldsymbol{R} \boldsymbol{t}$ attributable to meteorological factors by county and month

$142 \mathrm{a}, \mathrm{b}$ : the distribution of the fraction of reproduction number $(R t)$ attributable to temperature or specific

143 humidity (i.e., attributable fraction $[\mathrm{AF}]$ ) in each county; $\mathrm{c}, \mathrm{d}$ : the distribution of AF across months in the

144 study period. The black lines represent the 95\% confidence interval, which were calculated by 1000

145 Monte Carlo simulations.

\section{Discussion}

148 Using estimated reproduction numbers for 913 U.S. counties and controlling for temporal and spatial

149 trends and other potential confounders, we assessed the associations of air temperature and SH with the

150 transmission of SARS-CoV-2 and estimated the fractions of $R t$ attributable to temperature and SH. We

151 found both lower air temperature and lower SH to be significantly associated with increased Rt. During 
medRxiv preprint doi: https://doi.org/10.1101/2020.11.13.20231472; this version posted November $16,2020$. The copyright holder for this preprint (which was not certified by peer review) is the author/funder, who has granted medRxiv a license to display the preprint in perpetuity.

It is made available under a CC-BY-NC-ND 4.0 International license .

152 the study period, $5.10 \%$ of $R t$ was attributable to the deviation of temperature from its optimum value and

$15314.47 \%$ of $R t$ was attributable to the deviation of $\mathrm{SH}$ from its optimum value. Temperature and $\mathrm{SH}$

154 contributed more to transmission of SARS-CoV-2 in colder and drier counties and months than in warmer

155 and more humid counties and months. In March (the coldest month of our study period of March-

156 August), the AF for temperature was $11.00 \%$ and the AF for $\mathrm{SH}$ was $18.22 \%$ (Fig. 3). We can anticipate

157 higher AFs during the colder and drier months of January and February.

158 Associations of lower temperature and lower humidity with increased COVID-19 outcomes have been

159 reported by many previous studies. An early study in Wuhan, China reported that higher temperature and

160 RH were associated with decreased COVID-19 deaths ${ }^{21}$. Many multicity analyses in China also supported

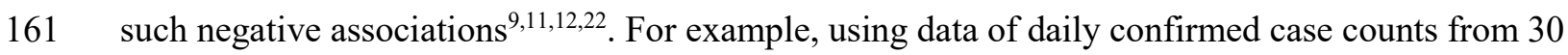

162 provincial capital cities of China, Liu et al. found that lower temperature and lower absolute humidity

163 were associated with higher COVID-19 case counts $^{11}$. Later, with the rapid spread of COVID-19 around

164 the world, studies in other countries emerged ${ }^{23-25}$. In the early stages of this pandemic in the U.S., a state-

165 level study of daily COVID-19 case counts observed a declining trend of reported cases with increasing

166 temperature up to $52^{\circ} \mathrm{F}^{23}$. Based on data from 166 countries worldwide, another study reported that a

$1671{ }^{\circ} \mathrm{C}$ increase in temperature and a $1 \%$ increase in $\mathrm{RH}$ were associated with a $3.08 \%$ and $0.85 \%$ reduction

168 in daily new cases, respectively ${ }^{25}$. However, many of these earlier studies were limited by short study

169 periods (e.g. 1-2 months), use of daily confirmed cases or deaths across countries for which there were

170 varying reporting biases, failure to account for the time lag between observed weather conditions and

171 when cases or deaths were recorded, or failure to account for time delays between infection acquisition

172 and case confirmation ${ }^{15}$.

173 By representing the transmissibility of SARS-CoV-2, the estimated daily reproduction number serves as a

174 better outcome than daily case counts. While case counts are subject to the influence of reporting delay

175 and underreporting, which vary across locations and are thus difficult to control, the reproduction number

176 is a direct estimate of the transmission rate of SARS-CoV-2, quantifying the average number of infections 
medRxiv preprint doi: https://doi.org/10.1101/2020.11.13.20231472; this version posted November 16, 2020. The copyright holder for this preprint (which was not certified by peer review) is the author/funder, who has granted medRxiv a license to display the preprint in perpetuity.

It is made available under a CC-BY-NC-ND 4.0 International license .

177 caused by one infection in the population. A small number of studies previously analyzed the association

178 between temperature or humidity and reproduction number ${ }^{16-18}$. Wang et al. found that a $1^{\circ} \mathrm{C}$ increase in

179 temperature was associated with a reduction in the effective reproduction number by 0.023 in China and

1800.020 in the U.S., and a $1 \%$ increase in RH was associated with a reduction in the effective reproduction

181 number by 0.0078 in China and 0.0080 in the U.S. ${ }^{16}$. These associations are consistent with our findings

182 but were not supported by two studies in China that examined the basic reproduction number: the first

183 found no association between temperature and SARS-CoV-2 transmission ${ }^{18}$; the second found no

184 association between absolute humidity and SARS-CoV-2 transmission ${ }^{17}$. However, these early studies

185 were limited by short observation periods at the beginning of the pandemic, and they did not account for

186 variations of testing capacity, reporting, human mobility, and population susceptibility in estimating

187 SARS-CoV-2 transmissibility.

188 In our study, Rt was estimated using a dynamic metapopulation model informed by human mobility data.

189 This mechanistic model accounted for unreported infections, reporting delays, and county-to-county

190 movement. We explicitly estimated the population susceptibility in each county, and removed its

191 influence in the calculation of $R t^{26}$ (see Methods). Further, model estimated population susceptibility has

192 been validated against independent seroprevalence studies ${ }^{26}$. Thus, our estimations account for spatial

193 heterogeneity in population immunity.

194 Another strength of our study was adjustment for a wide range of demographic and socioeconomic factors

195 in the main analysis, as well as for smoking and obesity, air pollution, and UV radiation in sensitivity

196 analyses. We also thoroughly controlled for spatially and temporally heterogenous unmeasured

197 confounders, such as implementation of and compliance with public health measures ${ }^{26}$, by simultaneously

198 controlling for temporal and spatial variations and including a random intercept to further account for

199 unmeasured county-level confounding (see Methods). This approach accounted for substantial differences

200 in the epidemic curves among counties (see Extended Data Fig. 2). 
201 Our findings are supported by laboratory evidence on the stability of SARS-CoV-2 as a function of

202 temperature and humidity. It has been reported that the virus' half-life in human nasal mucus and sputum

203 is shorter under conditions of higher temperature and RH than under conditions of lower temperature and

$204 \mathrm{RH}^{2}$. Similar findings were reported by other studies testing virus stability in virus transport medium ${ }^{3}$, in

205 aerosols, and on various surfaces ${ }^{27}$. Further, the SARS-CoV-2 half-life was found to be longer at lower

206 temperatures, and at both $22{ }^{\circ} \mathrm{C}$ and $27^{\circ} \mathrm{C}$, the half-life decreased as $\mathrm{RH}$ increased from $40 \%$ to $65 \%$ but

207 increased as $\mathrm{RH}$ increased from $65 \%$ to $85 \%{ }^{28}$. This result is consistent with the non-linear relationship

208 between SH and Rt observed in our study (Fig. 2b), in which there was an increasing trend of $R t$ from 9 to

$20915 \mathrm{~g} / \mathrm{kg}$ of SH superimposed on the overall decreasing trend.

210 The associations between temperature and humidity and SARS-CoV-2 transmissibility may be mediated

211 by airway antiviral defenses. Inhalation of cold and dry air can impair mucociliary clearance, a crucial

212 mechanism for elimination of inhaled pathogens ${ }^{29}$. Further, during the colder winter months people spend

213 more time indoors, which may facilitate virus transmission ${ }^{30}$. During these months, whether indoors or

214 outdoors, people are exposed to less UV radiation from the sun and therefore may produce less vitamin D

215 and other UV-induced mediators of immune function ${ }^{31}$.

216 We found that SH contributes more to SARS-CoV-2 transmission than temperature, which is consistent

217 with studies of influenza ${ }^{32}$. SH is more strongly associated with the observed seasonality of influenza in

218 temperate regions than either temperature or $\mathrm{RH}^{32-34}$. In developed countries, such as the U.S., people

219 spend approximately $90 \%$ of their time indoors ${ }^{35}$, especially during winter ${ }^{30}$. Although indoor temperature

220 is usually controlled, indoor humidity generally is not, and closely mirrors outdoor levels ${ }^{36-38}$, perhaps

221 explaining why ambient outdoor SH is more strongly associated with SARS-CoV-2 transmission than

222 ambient outdoor temperature. However, it remains unclear whether $\mathrm{SH}$ is the causative modulator of

223 SARS-CoV-2 transmission or is simply a useful indicator of the indoor environment and the combined

224 effects of temperature and $\mathrm{RH}$. 
225 In the sensitivity analyses, after adjusting for daily UV radiation, the estimated AF for temperature

226 decreased by about 30\% (Extended Data Table 2), indicating that UV radiation acted as a confounder.

227 This result is consistent with a recent study that found higher levels of solar UV radiation have a stronger

228 association than temperature or humidity with a decreased growth rate (exponential increase in cases) of

229 COVID-1939. In contrast, the fraction of $R t$ attributable to SH remained stable after adjusting for UV

230 radiation. Although it is unclear why UV radiation would serve as a confounder for temperature, but not

231 for $\mathrm{SH}$, this result does suggest that $\mathrm{SH}$ is a more robust predictor than temperature.

232 Several limitations should be noted. First, this is an ecological rather than an individual-level study, thus

233 making the study susceptible to the ecological fallacy. Second, due to the high correlation between

234 temperature and $\mathrm{SH}$, we were unable to explore whether the effects of temperature and humidity are

235 independent. Third, our study period was restricted to March-August; if we had been able to include an

236 entire year, including the colder months of November-February, our AF estimates for the entire study

237 period would likely have been larger.

\section{Conclusion}

239 Our findings indicate that cold and dry weather are moderately associated with increased SARS-CoV-2

240 transmissibility in the U.S., with absolute humidity (i.e., SH) playing a greater role than temperature.

241 More extensive public health interventions are needed to mitigate the increased transmissibility of SARS-

242 CoV-2 in winter months.

\section{Methods}

\section{Data collection}

245 We extracted hourly air temperature and SH from the North America Land Data Assimilation System

246 project $^{40}$, a near real-time dataset with a $0.125^{\circ} \times 0.125^{\circ}$ grid resolution. We spatially and temporally

247 averaged these data into daily county-level records. SH is the mass of water vapor in a unit mass of moist 248 air $(\mathrm{g} / \mathrm{kg})$. 
medRxiv preprint doi: https://doi.org/10.1101/2020.11.13.20231472; this version posted November 16, 2020. The copyright holder for this preprint (which was not certified by peer review) is the author/funder, who has granted medRxiv a license to display the preprint in perpetuity.

It is made available under a CC-BY-NC-ND 4.0 International license .

249 Other characteristics of each county, including geographic location, population density, demographic

250 structure of the population, socioeconomic factors, intensive care unit (ICU) bed capacity, health risk

251 factors, and long-term and short-term air pollution were collected from multiple sources. Geographic

252 coordinates, population density, median household income, percent of people older than 60 years, percent

253 black residents, percent Hispanic residents, percent owner-occupied housing, and percent residents aged

25425 years and over without a high school diploma were collected from the U.S. Census Bureau ${ }^{41}$. The

255 prevalence of smoking and obesity among adults in each county was obtained from the Robert Wood

256 Johnson Foundation's 2020 County Health Rankings ${ }^{42}$. Total ICU beds in each county were derived from

257 Kaiser Health News ${ }^{43}$. We extracted annual $\mathrm{PM}_{2.5}$ concentrations in the U.S. from 2014 to 2018 from the

$2580.01^{\circ} \times 0.01^{\circ}$ grid resolution $\mathrm{PM}_{2.5}$ estimation provided by the Atmospheric Composition Analysis

259 Group ${ }^{44}$, and calculated average $\mathrm{PM}_{2.5}$ levels during this 5-year period for each county to represent long-

260 term $\mathrm{PM}_{2.5}$ exposure (Extended Data Fig. 3). Short-term air quality data during the study period, including

261 daily mean $\mathrm{PM}_{2.5}$ and daily maximum 8-hour $\mathrm{O}_{3}$, were obtained from the United States Environmental

262 Protection Agency ${ }^{45}$. Daily downward UV radiation at the surface was extracted from the European

263 Centre for Medium-Range Weather Forecasts ERA5 climate reanalysis ${ }^{46}$, with data available before

264 August 2020.

265 Estimation of reproduction number

266 We estimated the daily reproduction number $(R t)$ in all 3,142 U.S. counties using a dynamic

267 metapopulation model informed by human mobility data ${ }^{26} . R t$ is the mean number of new infections

268 caused by a single infected person, given the public health measures in place, in a population in which

269 everyone is assumed to be susceptible. In the metapopulation model, two types of movement were

270 considered: daily work commuting and random movement. The transmission dynamics are depicted by a

271 set of ordinary differential equations ${ }^{26}$.

272 We explicitly simulated reported and unreported infections, for which separate transmission rates are

273 defined, and allowed transmission rates and ascertainment rates to vary across different counties. To infer 
274 key epidemiological parameters, we fit the transmission model to county-level daily cases and deaths

275 reported from March 15, 2020 to August 31, 2020. The estimated reproduction number is computed as

$276 R_{t}=\beta D[\alpha+(1-\alpha) \mu]$, where $\beta$ is county-specific transmission rate, $\mu$ is the relative transmissibility of

277 unreported infections, $\alpha$ is the county-specific ascertainment rate, and $D$ is the average duration of

278 infectiousness. To avoid possible inaccurate estimation for counties with few cases, we inferred $R t$ in the

279913 U.S. counties with at least 400 cumulative confirmed cases as of August 31, 2020 (Fig. 1). Details of

280 the model fitting and $R t$ estimation are reported elsewhere ${ }^{26}$.

281 Statistical analysis

282 All statistical analyses were conducted with R software (version 3.6.1) using the $m g c v$ and $d l n m$ package.

283 Exposure-response curves

284 Given the potential non-linear and temporally delayed effect of air temperature or SH, a distributed lag non-linear model (DLNM) ${ }^{47}$ combined with generalized additive mixed models (GAMM) was applied to estimate the associations of daily mean temperature or daily mean SH with SARS-CoV-2 Rt. Because of

287 the high correlation between air temperature and SH $(r=0.80$, Extended Data Table 3$)$, we analyzed

288 these two variables separately. The full model can be expressed as:

$289 \log \left(E\left(R_{i, t}\right)\right)=\alpha+t e\left(s\left(\right.\right.$ latitude $_{i}$, longitude $\left._{i}, \mathrm{k}=30\right), s\left(\right.$ time $\left.\left._{t}, \mathrm{k}=30\right)\right)+$ cb.temperature $($ or $\mathrm{cb} . \mathrm{SH})+$

$290 \beta_{1}\left(\right.$ population density $\left._{i}\right)+\beta_{2}\left(\right.$ percent black residents $\left._{i}\right)+\beta_{3}\left(\right.$ percent Hispanic residents $\left._{i}\right)+\beta_{4}\left(\right.$ precent people $^{2}$

291 older than 60 years $\left._{i}\right)+\beta_{5}\left(\right.$ median household income $\left._{i}\right)+\beta_{6}\left(\right.$ percent owner-occupied housing $\left._{i}\right)+\beta_{7}\left(\right.$ percent $^{2}$

292 residents older than 25 years without a high school diploma $i)+\beta_{8}($ number of ICU beds per 10,000

293 people $\left._{i}\right)+u_{i}$

294 where $E\left(R_{i, t}\right)$ refers to the expected $R t$ in county $i$ on day $t$, and $\alpha$ is the intercept. The time trend was

295 controlled by a flexible natural cubic spline over the range of study dates with a maximum of 30 knots; a

296 thin plate spline with a maximum of 30 knots was used to control the coordinates of the centroid of each

297 county. Due to the unique pattern of the non-linear time trend of $R t$ in each county (Extended Data Fig. 
2), we constructed tensor product smooths $(t e)$ of the splines of geographical coordinates and time, to better control for the temporal and spatial variations. Cb.temperature or cb.SH is a cross-basis term for the mean air temperature or mean SH. We modeled exposure-response associations using a natural cubic

301 spline with 3 degrees of freedom (df), and modeled the lag-response association using a natural cubic

302 spline with an intercept and $3 \mathrm{df}$ with a maximum lag of 13 days. We adjusted for county-level

303 characteristics, including population density, percent black residents, percent Hispanic residents, percent

304 people older than 60 years, median household income, percent owner-occupied housing, percent residents

305 older than 25 years without a high school diploma, and number of ICU beds per 10,000 people. The

306 random effect of county $\left(u_{i}\right)$ was considered in the model to further control for unmeasured county-level

307 confounding. To obtain more precise estimates, we excluded from the analysis days during which $R t$ was

308 less than 0.2 .

309 Based on the estimated exposure-response curves, between the $1^{\text {st }}$ and the $99^{\text {th }}$ percentiles of the

310 distribution of air temperature and $\mathrm{SH}$, we determined the value of exposure associated with the lowest $R t$

311 to be the optimum temperature or the optimum $\mathrm{SH}$, respectively. The natural cubic spline functions of the

312 exposure-response relationship were then re-centered with the optimum temperature and SH as reference

313 values. We report the cumulative relative risk of $R t$ associated with daily temperature or SH exposure in

314 the previous two weeks ( 0 to 13 lag days) as the percent changes of $R t$ when comparing the daily

315 exposure with the optimum reference values (i.e., the cumulative relative risk of $R t$ equals one and the

316 percent change of $R t$ equals zero when the temperature or SH exposure is at its optimum value).

\section{Attribution of $\boldsymbol{R} \boldsymbol{t}$ to temperature or $\mathbf{S H}$}

318 We used the optimum value of temperature or SH as the reference value for calculating the fraction of $R t$

319 attributable to temperature or SH; i.e., the attributable fraction (AF). For these calculations, we assumed

320 that the associations of temperature and SH with $R t$ were consistent across the counties. For each day in

321 each county, based on the cumulative lagged effect (cumulative relative risk) corresponding to the

322 temperature or $\mathrm{SH}$ of that day, we calculated the attributable $R t$ in the current and next 13 days, using a 
medRxiv preprint doi: https://doi.org/10.1101/2020.11.13.20231472; this version posted November 16, 2020. The copyright holder for this preprint (which was not certified by peer review) is the author/funder, who has granted medRxiv a license to display the preprint in perpetuity.

It is made available under a CC-BY-NC-ND 4.0 International license .

323 previously established method ${ }^{48}$. Specifically, in a given county, the $R t$ attributable to a temperature or a

$324 \mathrm{SH}\left(x_{t}\right)$ for a given day $t$ was defined as the attributable absolute excess of $\operatorname{Rt}\left(A E_{x, t}\right.$, the excess

325 reproduction number on day $t$ attributable to the deviation of temperature or SH from the optimum value)

326 and the attributable fraction of $\operatorname{Rt}\left(A F_{x}\right.$, the fraction of $R t$ attributable to the deviation of temperature or

327 SH from the optimum value), each accumulated over the current and next 13 days. The formula can be

328 expressed as

$329 A F_{x, t}=1-\exp \left(-\sum_{l=0}^{13} \beta_{x_{t}, l}\right)$ and $A E_{x, t}=A F_{x, t} \times \sum_{l=0}^{13} \frac{n_{t+1}}{13+1}$, where $n_{t}$ is the $R t$ on day $t$, and $\sum_{l=0}^{13} \beta_{x_{t}, l}$

330 is the overall cumulative log-relative risk for exposure $x_{t}$ on day $t$ obtained by the exposure-response

331 curves re-centered on the optimum values. Then, the total absolute excess of $R t$ attributable to

332 temperature or SH in each county was calculated by summing the absolute excesses of all days during the

333 study period, and the attributable fraction was calculated by dividing the total absolute excess of $R t$ for the

334 county by the sum of the Rt of all days during the study period for the county. The attributable fraction for

335 the 913 counties combined was calculated in a similar manner at the national level. We derived the $95 \%$

336 empirical confidence intervals $(95 \% \mathrm{eCI})$ for the attributable absolute excess and attributable fraction by

3371000 Monte Carlo simulations ${ }^{48}$. We also calculated the attributable fractions by month in the study

338 period.

339 Sensitivity analyses

340 We conducted several sensitivity analyses to test the robustness of our results: a) the lag dimension was

341 redefined using a natural cubic spline and three equally placed internal knots in the log scale; b) an

342 alternative four df was used in the cross-basis term for air temperature or SH in the exposure-response

343 function; c) time trend and geographical coordinates were controlled by a thin plate spline, instead of the

344 tensor product smooth; d) all demographic and socioeconomic variables were excluded from the model;

345 e) adjustment for the prevalence of smoking and obesity among adults was included in the model; f)

346 additional adjustment was made for the average $\mathrm{PM}_{2.5}$ concentration in each county during 2014-2018 
medRxiv preprint doi: https://doi.org/10.1101/2020.11.13.20231472; this version posted November 16, 2020. The copyright holder for this preprint (which was not certified by peer review) is the author/funder, who has granted medRxiv a license to display the preprint in perpetuity. It is made available under a CC-BY-NC-ND 4.0 International license .

347 g) additional adjustment was made for daily mean $\mathrm{PM}_{2.5}$, daily maximum 8-hour $\mathrm{O}_{3}$, and daily downward

348 UV radiation at the surface. For daily covariates with available data in only some of the counties or study

349 period, the results of sensitivity analyses were compared to the main model re-run on the same partial

350 dataset. 
medRxiv preprint doi: https://doi.org/10.1101/2020.11.13.20231472; this version posted November 16, 2020. The copyright holder for this preprint (which was not certified by peer review) is the author/funder, who has granted medRxiv a license to display the preprint in perpetuity.

It is made available under a CC-BY-NC-ND 4.0 International license .

\section{Acknowledgements}

352 Y.M. received funding from the China Scholarship Council (201906320022). S.P. and J.S. acknowledged

353 funding from the National Institutes of Health (GM110748) and the National Science Foundation (DMS-

354 2027369), as well as a gift from the Morris-Singer Foundation. R.D. received funding from the High Tide

355 Foundation.

356 Author contributions

357 K.C. conceived of and supervised the conduct of this study and edited the manuscript. J.S. and R.D.

358 contributed to the study design, interpretation of results, and manuscript revision. S.P. estimated the

359 reproduction number and contributed to the writing. Y.M. conducted formal analyses and drafted the

360 manuscript. All authors reviewed and approved the final version of this manuscript.

\section{Competing interests}

362 J.S. and Columbia University disclose partial ownership of SK Analytics. J.S. discloses consulting for

363 BNI. All other authors declare no competing interests.

\section{Data availability}

365 Estimates of county-level reproduction number are available at https://github.com/shaman-

$366 \underline{\text { lab/Counterfactual }}$

367 The data sets used in the study are publicly available from the following locations:

368 Hourly air temperature and specific humidity data:

369 https://disc.gsfc.nasa.gov/datasets/NLDAS FORA0125 H 002/summary?keywords=NLDAS

370 Population density, median household income, percent of people older than 60 years, percent black

371 residents, percent Hispanic residents, percent owner-occupied housing, and percent residents aged 25

372 years and over without a high school diploma: https:/www.census.gov/data/tables.html 
medRxiv preprint doi: https://doi.org/10.1101/2020.11.13.20231472; this version posted November 16, 2020. The copyright holder for this preprint (which was not certified by peer review) is the author/funder, who has granted medRxiv a license to display the preprint in perpetuity. It is made available under a CC-BY-NC-ND 4.0 International license.

373 U.S. county boundary: https:/www.census.gov/geographies/mapping-files/time-series/geo/cartographic-

374 boundary.html

375 Prevalence of smoking and obesity among adults in each county:

376 https://www.countyhealthrankings.org/explore-health-rankings/rankings-data-documentation

377 Total ICU beds in each county: https://khn.org/news/as-coronavirus-spreads-widely-millions-of-older-

378 americans-live-in-counties-with-no-icu-beds/

379 Annual $\mathrm{PM}_{2.5}$ concentrations in the U.S. from 2014 to 2018 :

380 http://fizz.phys.dal.ca/ atmos/martin/?page_id=140

381 Short-term daily mean $\mathrm{PM}_{2.5}$ and daily maximum 8-hour $\mathrm{O}_{3}$ : https://www.epa.gov/outdoor-air-quality-

382 data/download-daily-data

383 Daily downward UV radiation at the surface:

384 https://cds.climate.copernicus.eu/cdsapp\#!/dataset/reanalysis-era5-single-levels?tab=overview

\section{Code availability}

$386 \mathrm{R}$ code for this analysis will be available at https://github.com/CHENlab-Yale/COVID-Climate 
402

403

404

405

406

407

408

409

410

\section{Reference}

1. Dong, E., Du, H. \& Gardner, L. An interactive web-based dashboard to track COVID-19 in real time. The Lancet Infectious Diseases 20, 533-534 (2020).

2. Matson, M.J., et al. Effect of environmental conditions on SARS-CoV-2 stability in human nasal mucus and sputum. Emerg Infect Dis 26, 2276-2278 (2020).

3. Chin, A.W.H., et al. Stability of SARS-CoV-2 in different environmental conditions. Lancet Microbe 1, e10 (2020).

4. Sooryanarain, H. \& Elankumaran, S. Environmental role in influenza virus outbreaks. Annu Rev Anim Biosci 3, 347-373 (2015).

5. Tan, J., et al. An initial investigation of the association between the SARS outbreak and weather: with the view of the environmental temperature and its variation. J Epidemiol Community Health 59, 186-192 (2005).

6. Abdul-Rasool, S. \& Fielding, B.C. Understanding human coronavirus HCoV-NL63. Open Virol J 4, 76-84 (2010).

7. $\quad$ Esper, F., Weibel, C., Ferguson, D., Landry, M.L. \& Kahn, J.S. Coronavirus HKU1 infection in the United States. Emerg Infect Dis 12, 775-779 (2006).

8. Carlson, C.J., Gomez, A.C.R., Bansal, S. \& Ryan, S.J. Misconceptions about weather and seasonality must not misguide COVID-19 response. Nat Commun 11, 4312 (2020).

9. Shi, P., et al. Impact of temperature on the dynamics of the COVID-19 outbreak in China. Sci Total Environ 728, 138890 (2020).

10. Prata, D.N., Rodrigues, W. \& Bermejo, P.H. Temperature significantly changes COVID-19 transmission in (sub)tropical cities of Brazil. Sci Total Environ 729, 138862 (2020).

11. Liu, J., et al. Impact of meteorological factors on the COVID-19 transmission: A multi-city study in China. Sci Total Environ 726, 138513 (2020).

12. Xie, J. \& Zhu, Y. Association between ambient temperature and COVID-19 infection in 122 cities from China. Sci Total Environ 724, 138201 (2020).

13. Pani, S.K., Lin, N.H. \& RavindraBabu, S. Association of COVID-19 pandemic with meteorological parameters over Singapore. Sci Total Environ 740, 140112 (2020).

14. Li, R., et al. Substantial undocumented infection facilitates the rapid dissemination of novel coronavirus (SARS-CoV-2). Science 368, 489-493 (2020).

15. Smit, A.J., et al. Winter is coming: a southern hemisphere perspective of the environmental drivers of SARS-CoV-2 and the potential seasonality of COVID-19. Int J Environ Res Public Health 17, 5634 (2020).

16. Wang, J., et al. High temperature and high humidity reduce the transmission of COVID-19. SSRN (2020).

17. Luo, W., et al. The role of absolute humidity on transmission rates of the COVID-19 outbreak. medRxiv, 2020.2002.2012.20022467 (2020).

18. Yao, Y., et al. No association of COVID-19 transmission with temperature or UV radiation in Chinese cities. Eur Respir J 55, 2000517 (2020).

19. Gostic, K.M., et al. Practical considerations for measuring the effective reproductive number, Rt. medRxiv (2020).

20. Baker, R.E., Yang, W., Vecchi, G.A., Metcalf, C.J.E. \& Grenfell, B.T. Susceptible supply limits the role of climate in the early SARS-CoV-2 pandemic. Science 369, 315-319 (2020).

21. Peak, C.M., et al. Individual quarantine versus active monitoring of contacts for the mitigation of COVID-19: a modelling study. The Lancet Infectious Diseases (2020).

22. Qi, H., et al. COVID-19 transmission in Mainland China is associated with temperature and humidity: A time-series analysis. Sci Total Environ 728, 138778 (2020).

23. Sehra, S.T., Salciccioli, J.D., Wiebe, D.J., Fundin, S. \& Baker, J.F. Maximum daily temperature, precipitation, ultra-violet light and rates of transmission of SARS-Cov-2 in the United States. Clin Infect Dis (2020). 
24. Runkle, J.D., et al. Short-term effects of specific humidity and temperature on COVID-19 morbidity in select US cities. Sci Total Environ 740, 140093 (2020).

25. $\mathrm{Wu}, \mathrm{Y}$., et al. Effects of temperature and humidity on the daily new cases and new deaths of COVID-19 in 166 countries. Sci Total Environ 729, 139051 (2020).

26. Pei, S., Kandula, S. \& Shaman, J. Differential effects of intervention timing on COVID-19 spread in the United States. Science Advances, eabd6370 (2020).

27. van Doremalen, N., et al. Aerosol and surface stability of SARS-CoV-2 as compared with SARSCoV-1. N Engl J Med 382, 1564-1567 (2020).

28. Morris, D.H., et al. The effect of temperature and humidity on the stability of SARS-CoV-2 and other enveloped viruses. bioRxiv, 2020.2010.2016.341883 (2020).

29. Moriyama, M., Hugentobler, W.J. \& Iwasaki, A. Seasonality of respiratory viral infections. Annual Review of Virology 7, 83-101 (2020).

30. Shaman, J. \& Galanti, M. Will SARS-CoV-2 become endemic? Science, eabe5960 (2020).

31. Hart, P.H., Gorman, S. \& Finlay-Jones, J.J. Modulation of the immune system by UV radiation: more than just the effects of vitamin D? Nature Reviews Immunology 11, 584-596 (2011).

32. Shaman, J. \& Kohn, M. Absolute humidity modulates influenza survival, transmission, and seasonality. Proc Natl Acad Sci U S A 106, 3243-3248 (2009).

33. Shaman, J., Goldstein, E. \& Lipsitch, M. Absolute humidity and pandemic versus epidemic influenza. Am J Epidemiol 173, 127-135 (2011).

34. Shaman, J., Pitzer, V.E., Viboud, C., Grenfell, B.T. \& Lipsitch, M. Absolute humidity and the seasonal onset of influenza in the continental United States. PLoS Biol 8, e1000316 (2010).

35. Klepeis, N.E., et al. The National Human Activity Pattern Survey (NHAPS): a resource for assessing exposure to environmental pollutants. J Expo Anal Environ Epidemiol 11, 231-252 (2001).

36. Shaman, J., Kandula, S., Yang, W. \& Karspeck, A. The use of ambient humidity conditions to improve influenza forecast. PLoS Comput Biol 13, e1005844 (2017).

37. Quinn, A. \& Shaman, J. Indoor temperature and humidity in New York City apartments during winter. Science of The Total Environment 583, 29-35 (2017).

38. Nguyen, J.L., Schwartz, J. \& Dockery, D.W. The relationship between indoor and outdoor temperature, apparent temperature, relative humidity, and absolute humidity. Indoor Air 24, 103112 (2014).

39. Merow, C. \& Urban, M.C. Seasonality and uncertainty in global COVID-19 growth rates. Proceedings of the National Academy of Sciences, 202008590 (2020).

40. Cosgrove, B.A., et al. Real-time and retrospective forcing in the North American Land Data Assimilation System (NLDAS) project. Journal of Geophysical Research: Atmospheres 108(2003).

41. United States Census Bureau. Tables. (2020).

42. Robert Wood Johnson Foundation. 2020 County Health Rankings. (2020).

43. Kaiser Health News. Millions Of Older Americans Live In Counties With No ICU Beds As Pandemic Intensifies. (2020).

44. van Donkelaar, A., Martin, R.V., Li, C. \& Burnett, R.T. Regional estimates of chemical composition of fine particulate matter using a combined geoscience-statistical method with information from satellites, models, and monitors. Environ Sci Technol 53, 2595-2611 (2019).

45. United States Environmental Protection Agency. Outdoor Air Quality Data. (2020).

46. European Centre for Medium-Range Weather Forecasts. ERA5 hourly data on single levels from 1979 to present. (2018).

47. Gasparrini, A., Armstrong, B. \& Kenward, M.G. Distributed lag non-linear models. Stat Med 29, 2224-2234 (2010).

48. Gasparrini, A. \& Leone, M. Attributable risk from distributed lag models. BMC Med Res Methodol 14, 55 (2014). 
medRxiv preprint doi: https://doi.org/10.1101/2020.11.13.20231472; this version posted November 16, 2020. The copyright holder for this preprint (which was not certified by peer review) is the author/funder, who has granted medRxiv a license to display the preprint in perpetuity.

It is made available under a CC-BY-NC-ND 4.0 International license .

488

489

490

491

492
49. Wu, X., Nethery, R.C., Sabath, M.B., Braun, D. \& Dominici, F. Air pollution and COVID-19 mortality in the United States: Strengths and limitations of an ecological regression analysis. Sci $A d v$ 6(2020). 
medRxiv preprint doi: https://doi.org/10.1101/2020.11.13.20231472; this version posted November 16, 2020. The copyright holder for this preprint (which was not certified by peer review) is the author/funder, who has granted medRxiv a license to display the preprint in perpetuity.

It is made available under a CC-BY-NC-ND 4.0 International license .

493 Extended Data Fig. 1. Lag-response relationships of air temperature $\left({ }^{\circ} \mathrm{C}\right)$ or specific

494 humidity (g/kg) with reproduction number $(\boldsymbol{R} t)$.

495 These curves are computed for the $10^{\text {th }}$ percentile of air temperature and specific humidity vs. the

496 optimum values on different lag days; the grey areas display the $95 \%$ confidence interval. The effect

497 estimates show a decreasing trend in the lag dimension, diminishing to a small non-significant effect on

$498 \quad$ lag day 13.

499 Extended Data Fig. 2. Daily $R t$ from March 15 to August 31 in the largest county in each

500 state.

501 Black dots represent the daily value of reproduction number $(R t)$ in the largest county in each U.S. state.

502 Blue lines show the trend of $R t$ through time, fitted by local polynomial regression; the light blue areas

503 display the $95 \%$ confidence interval.

504 Extended Data Fig. 3. Distribution of average $\mathbf{P M}_{2.5}$ concentration during 2014-2018.

505 This map displays the county-level average $\mathrm{PM}_{2.5}$ concentration during 2014-2018, extracted from the

$506 \quad \mathrm{PM}_{2.5}$ estimation provided by Atmospheric Composition Analysis Group. 